American Journal of

Supply Chain Management

(AJSCM)

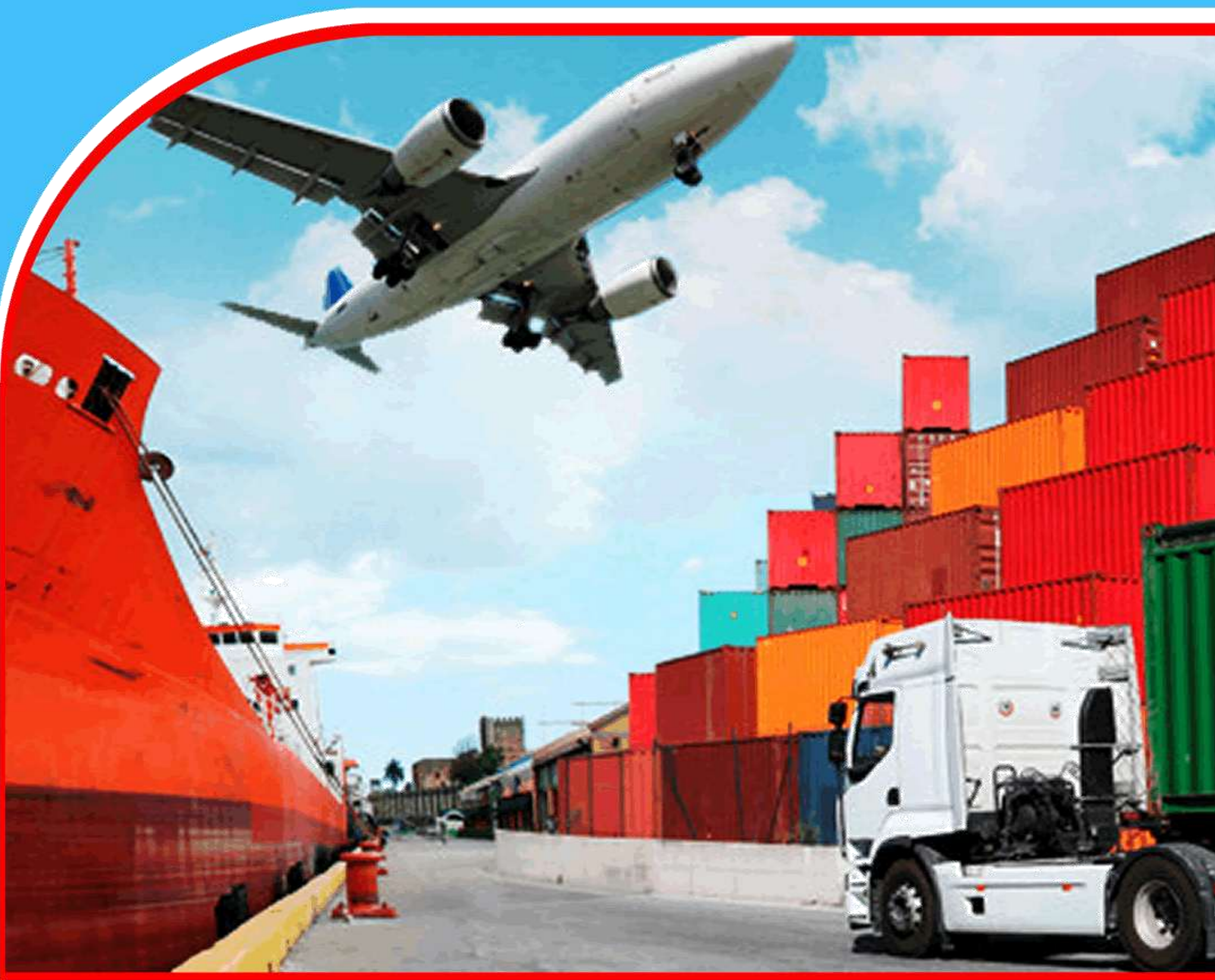

MANAGERIAL COMPETENCIES AND SUPPLY

CHAIN PERFORMANCE OF RELIEF AID

ORGANIZATIONS IN WESTERN UGANDA

Wilbroad Aryatwijuka

Prof. Nixon Kamukama

Dr. Nsambu Kijjambu Frederick

Dr Aloysius Rukundo

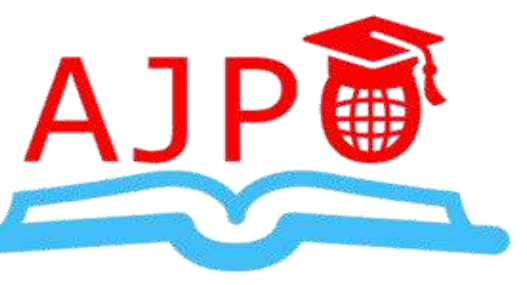




\title{
MANAGERIAL COMPETENCIES AND SUPPLY CHAIN PERFORMANCE OF RELIEF AID ORGANIZATIONS IN WESTERN UGANDA
}

\author{
Wilbroad Aryatwijuka ${ }^{1}$, Prof Nixon Kamukama ${ }^{2}$, Dr Nsambu Kijjambu Frederick ${ }^{2}$ \& Dr \\ Aloysius Rukundo ${ }^{3}$ \\ ${ }^{1}$ Department of Procurement and Marketing, Mbarara University of science and Technology, \\ Mbarara, Uganda. \\ ${ }^{2}$ Department of Accounting and Finance, Mbarara University of science and Technology, \\ Mbarara, Uganda. \\ ${ }^{3}$ Department of Education Foundations, Mbarara University of science and Technology, \\ Mbarara, Uganda.
}

\begin{abstract}
Purpose-The paper presents the influence of managerial competencies on supply chain performance of relief aid organizations in western Uganda.

Methods-The study employed a cross-sectional and quantitative research design comprising 105 relief aid organizations operating in western Uganda. Data was analyzed using SPSSv22, to generate descriptive statistics, run correlation and hierarchical regression analysis.

Findings-The findings showed a positive significant influence of managerial competencies on supply chain performance of relief aid organizations in western Uganda.

Limitations-The study did not examine the influence of other factors such as the other supply chain enablers which include infrastructure on humanitarian supply chain performance. The focus was on the influence of managerial competencies on supply chain performance.

Unique contribution to practice and policy-relief aid organizations should emphasize attracting, training and retaining staff with professional, social and personal competencies to ensure efficient delivery of relief supplies.
\end{abstract}

Key words: Managerial competencies, Supply chain performance, relief aid organizations. 


\section{Introduction}

In the current study, the researchers further the understanding of supply chain performance of relief aid organizations in western Uganda. Specifically, the researchers report about the influence of managerial competencies in operating efficient relief supply chains in Uganda, a country deficient of humanitarian supply chain literature. Supply chain performance is the ability of the supply chain to deliver the right supplies, sourced at the right price, from the right source, delivered to the right people, at the right time and in the right condition (CSCMP, 2010; Zulfiya, 2017).In any relief operation supply chain activities count for over $80 \%$ of the total humanitarian response budget (Van Wassenhove, 2006; Blecken, 2010; Majewski et al., 2010; Christopher, 2011). Relief aid organizations can only register the required efficiency by having staff with professional, social and personal competencies (Veliu, 2017: Kovács \& Tatham, 2010; Shanaka et al., 2017). This study assesses state of relief operations in developing countries like Uganda, specifically on how managerial competencies impact supply chain performance.

Uganda plays host to over 1.3 million refugees, residing mainly in the refugee settlements situated in the western part of the country (OPM, 2017). The wellbeing of these refugees depends largely on the Ugandan government supported by relief aid organizations who ensure that these refugees are sheltered, fed and medicated (Turyamureeba, 2017). Despite their crucial role, relief aid organizations in Uganda continue to experience operational challenges as evidenced by reports of relief supplies not reaching the intended beneficiaries (Ben, 2018; Biryabarema, 2018). These challenges have been manifested in terms of inaccurate forecast, corruption and theft of relief supplies (Kabasongora, 2011; Sserunjogi, 2018). Such managerial deficiencies hinder the proper functioning of the supply chain and ultimately inhibits the delivery of relief services.

While hitherto there has been increased research in the field humanitarian supply chain performance (Kunz and Reiner, 2012), more so in exploring the influence of managerial competencies on performance (Kovács \& Tatham 2010; Shanaka et al., 2017), the same needs to be examined in Uganda considering the varied contexts. Additionally most studies have focused on supply chain performance in the upstream (Abdifatah, 2012; Nyamu, 2012) and Magadi, 2018). This study focuses on the downstream of the supply chain as it is where the refugee is located and is the reason for relief operations and more so existence of relief aid organizations. It also important to note that the never-ending refugee crisis necessitates more research in order to get ways of improving relief operations (Amin et al., 2018; Kunz and Reiner, 2012). Due to this background, it can be urged that a study of the influence of managerial competencies on supply chain performance of relief aid organizations in western Uganda is required. Since the current context of the study is devoid of literature, the study provides a contribution to the body of knowledge on how efficiency can be realized in relief supply chains. The rest of the paper presents literature review, methodology, results, discussion conclusions implications and recommendations.

\section{Literature review.}

\subsection{The concept of supply chain performance}

According to the Council of Supply Chain Management Professionals, (CSCMP,2010) a supply chain is a network that brings a product from raw material stage in the upstream through production and delivery up to the final consumer in the downstream with the associated information flow. 
Humanitarian supply chain performance refers to the ability of a supply chain to procure the right supplies from the right source, at the right cost, transported in the right condition, to the right place, delivered to the right place and distributed to the right beneficiaries (Blecken et al, 2009; Havisto and Kovacs, 2014). In atypical humanitarian operation, supply chain performance is often measured according to cost, quality, speed and flexibility (Beamon \& Balcik, 2008). Quality looks at whether supplies are fit for purpose, whether orders are accurate and whether the estimation of requirements was accurate (Haavisto \& Kovacs, 2014). The speed of the operation is examined from the time it takes to respond to the need and make actual deliveries to the beneficiary, this looks at the lead times (Strakos, 2013). Cost of the relief operation is assessed basing on costs of acquiring supplies, cost incurred on transporting supplies, cost of storage and handling (Blecken et al, 2009; Schulz \& Heigh, 2009). Flexibility is gauged from how an organisation is able to vary supply mix, meet unexpected demand, change delivery and supply schedules according to the situation (Beamon \& Balcik, 2008). Various theories have been used to explain the concept of performance, the current study is no exception as seen in the next section which presents the theory that underpins the study.

\subsection{The upper echelon theory}

Advanced by March and Simon (1958), the theory looks at what managers bring into the organisation when they are recruited in terms of skills, values and behaviors so as to make better decisions. This implies that management decisions and actions are not just influenced by the operational environment but by the manager's own understanding and knowhow. The theory further holds that organizations are a mirror image of management in terms of skills, knowledge, experience and these lead to attainment of organizational goals as such abilities are a precondition for success (Finkelstein et al., 2009) . According to Grant (2005), companies with managers who are visionary in terms of strategic direction and competences like professional, social and personal are able to balance resources with objectives and goals. The theory therefore places organizational performance and success to what competencies managers possess in terms of personal, social or professional characteristics (Kamukama et al, 2017). For this reason, there is a direct relationship between managerial competencies and organizational performance (Hambrick \&Mason, 1984).Decisions made by operational actors especially those in upper echelons are very crucial for relief aid organizations to realize the desired level of performance. This is because of their strategic direction which influences the day to day operations.

\subsection{Managerial competencies and supply chain performance.}

Managerial competencies refer to abilities, skills and knowledge required to perform a task effectively and efficiently in accordance with agreed standards (Kamukama et al, 2017). Extant literature shows that supply chain performance depends on the ability of relief aid organizations to have competent staff who will always make decisions that impact on the success of relief operations (Haddad, 2017; Kovacs et al .2010). Ashley et al., (2016) opine that supply manger capabilities like forecasting, planning and operation management skills are very crucial for the performance of any supply chain. Similarly, Onyango (2016) in a study conducted among relief aid organizations in Kenya discovered a positive association between managerial competencies 
and performance of supply chains of relief organizations however the focus was on the upstream side of the supply chain.

In the same vein, Kovács, G., Tatham, P and Larson, P. (2012) assert that performance of organizations depend on the logistic skills possessed by their staff. Logistic activates are vital in any supply chain and once they are well executed, a relief operation will be considered successful. Furthermore, Kamukama et al. (2017) posit that the performance of an organisation is as result of the competencies of staff who execute day to day operations since staff are the torch bearers for the strategic direction of their organizations. Additionally, a study conducted by Long et al., (2018) in the banking sector of Nigeria, found that competencies of human resources who are in charge of the bank operations contribute to the performance the institution. Seate et al (2016) note that job performance depends on the level of expertise of the staff, this implies that performance of relief activities depends on the skills of the staff. Further still, (Shanaka et al., 2017 and Veliu, 2017) observe, that performance of any organisation hinges on the social, professional and personal competencies of staff who at times operate in complex circumstances. Complexity is part of relief operations and this means that the operational environment can at times have a serious effect on the results organizations register even with skilled staff. This is consistent with the study of Cetin (2010) whose findings point to a weak relationship between competence and performance owing to the complex and diverse environments that staff operate in. From the above discussion, it follows that there is a difference in opinion on how managerial competencies predict performance. Therefore this study is necessary to establish the relationship between managerial competencies and supply chain performance of relief aid organizations in western Uganda. The focus for this study is the downstream of the supply chain where relief beneficiaries are placed in the supply chain and hence it was hypothesized that;

H1: Managerial competences positively influence supply chain performance of relief aid organizations in western Uganda.

\section{Methodology}

\subsection{Research design}

The study utilized a cross-sectional and quantitative research design including 105 out of 150 relief aid organizations operating in western Uganda as per the statistics from office of the Prime Minister (OPM), (2018). Organizations were stratified according to their areas of operation namely food security, water and sanitation, education, health and logistics (Amin et al., 2018). Simple random sampling was used to ensure every organisation had an equal chance of being selected (Creswell, 2013). Purposive sampling was used to pick staff involved in supply chain activities as they could provide the required information to the study. Data was collected from at least 5 (five) members per organisation including the administrative officer, stores staff, logistics officer, procurement manager and field officer. The collected data was aggregated at and analyzed at firm level so as to get the stand point of a particular organisation on a given subject under inquiry as seen in Table II. 


\subsection{Operationalization and measurement of variables}

Study variables in this study were measured on a continuous scale using the items previously developed, confirmed and published by other academics (Kamukama et al., 2017). A pilot study was undertaken to adapt the items and tools to the study setting and checked for validity and reliability. Additionally, the items were anchored on 5-point likert scale in a range of 1 (strongly agree) to 5 (strongly disagree), these were measured as seen below:

- Managerial competencies: Professional, social and personal competencies of the organizational staff (Veliu, 2017)

- Supply chain Performance: Cost, quality, speed and flexibility (Beamon \& Balcik, 2008 Blecken et al.2009; Schulz \& Heigh, 2009)

\subsection{Data management and analysis}

In addressing common method bias, data was collected from at least five (5) participants per organisation. To address possible response pattern bias, questions were negatively phrased to as humps (Idaszak \& Drasgow, 1997). Consistent with Kasekende et al, (2015), exploratory factor analysis was used to statistically address common method bias. From the exploratory factor analysis results, many factors were generated with none individually accounting for more than $50 \%$ of the variance for a particular variable proving that the study suffered no common method variance.

For face and content validity, a team comprising policy makers, practitioners and academicians validated the questionnaire. The content validity index for managerial competencies were 0.91 while the score for supply chain performance was 0.95 which proved that the questionnaire captured constructs under study and so was suitable for use in the study.

To ascertain the reliability of the data collection instrument, chronbach alpha coefficients $(\alpha)$ were computed aided by SPSS v22. The scores for Managerial competencies were 0.90 while the alpha for supply chain performance was 0.91 . These scores proved that the questionnaire was suitable use in the study as the scores were above the acceptable cut off of 0.7 (Field 2009). Furthermore, the composite reliability of the study variables was computed. The scores for managerial competencies 0.76 while supply chain performance was 0.77 . These scores were sufficient as they were above the acceptable cut off of 0.6 (Fornell \& Larcker, 1981).

Additionally, convergent and discriminant validity were computed. Using varimax (orthogonal) rotation exploratory factor analysis was run on items that explained managerial competencies and supply chain performance. For managerial competencies, the Kaiser Meyer Oklin (KMO) was at .877 while for supply chain performance the KMO was 0.933 . The scores were considered great as they were above the acceptable cut off of 0.5 (Field, 2009). Similarly, managerial competencies and supply chain performance's Bartlett's test of Sphericity were both significant at .000 a sign that there was an inter-item correlation and hence the results were fit for Principal component analysis (PCA). The components had Eigen values over Kaiser Criterion of 1 and the combination of the items explained $73.1 \%$ for managerial competencies while it was $79.7 \%$ of the variance. The high factor structure loadings were proof of convergent and discriminant validity with no major cross-loadings between factors. 


\subsection{Results}

\subsubsection{Demographic results}

Of the 420 questionnaires distributed, 395 were returned and 386 used. The 9 questionnaires that were not used, were found out to be improperly filled. Therefore response rate was $91.9 \%$. This is a very good response rate since it was above $70 \%$ (Creswell 2013).

\section{Table I: Respondent Characteristics}

\begin{tabular}{llll}
\hline Item & Category & Frequency & Percentage \\
\hline Gender & Male & 263 & 68.1 \\
Level of education & Female & 123 & 31.9 \\
& Certificate & 24 & 6.2 \\
& Diploma & 67 & 17.4 \\
& Degree & 208 & 53.9 \\
Years of service & Post graduate & 87 & 22.5 \\
& 0-1 year & 26 & 6.7 \\
Position & 2-5 years & 157 & 40.7 \\
& Above 5years & 203 & 52.6 \\
& Procurement Manager & 40 & 10.4 \\
& Logistics officer & 62 & 16.1 \\
& Stores staff & 91 & 23.6 \\
& Field officer & 149 & 38.6 \\
& Administrative officer & 44 & 11.4 \\
\hline
\end{tabular}

Notes: N=386 Source: Primary data 2020.

From Table I which shows the demographic characteristics of the respondents, it is observed that majority $(68 \%)$ of the respondents were males with a bachelor's degree $(53.9 \%)$, were field officers $(38.6 \%)$ and had worked for more than 5 years 203(52.6\%).

Table II: Organisational characteristics

\begin{tabular}{llll}
\hline Item & Category & Frequency & Percentage \\
\hline Cluster & Logistics & 42 & 40 \\
& Food Security & 32 & 30 \\
& Water and Sanitation & 9 & 8.6 \\
& Health & 10 & 10.5 \\
Years in relief operations & Education & 12 & 10.9 \\
& $0-5$ years & 4 & 3.8 \\
Location of Settlement & 6-10 years & 23 & 21.9 \\
& Above 10 years & 78 & 74.3 \\
& Oruchinga & 4 & 3.8 \\
& Nakivale & 37 & 35.2 \\
& Rwamwanja & 19 & 18.1 \\
& Kyaka & 30 & 28.6 \\
& Kyangwali & 15 & 14.3 \\
\hline
\end{tabular}

Notes: N=105 Source: Primary data 2020. 
The aggregated firm characteristics as presented in Table II, indicating that majority of relief aid organizations belong to the logistics cluster (40\%), operate from Nakivale refugee settlement $(35.2 \%)$ and had been in operation for more than 10 years $(74.3 \%)$.

\subsubsection{Correlation analysis}

Correlation analysis was used to establish the relationship between managerial competencies and supply chain performance.

\begin{tabular}{llllllllll}
\multicolumn{2}{l}{ Table III: Correlation results } \\
\hline Construct & $\mathbf{1}$ & $\mathbf{2}$ & $\mathbf{3}$ & $\mathbf{4}$ & $\mathbf{5}$ & $\mathbf{6}$ & $\mathbf{7}$ & $\mathbf{8}$ & 9 \\
\hline M. C(1) & 1 & & & & & & & & \\
Prof. C(2) & $.715^{* *}$ & 1 & & & & & & & \\
S.C(3) & $.789^{* *}$ & $.788^{* *}$ & 1 & & & & & & \\
P.C (4) & $.634^{* *}$ & $.508^{* *}$ & $.557^{* *}$ & 1 & & & & \\
Performance (5) & $.532^{* *}$ & $.428^{* *}$ & $.228^{*}$ & $.597^{* *}$ & 1 & & & \\
Cost (6) & .188 & .176 & 192 & $.288^{*}$ & $.554^{* *}$ & 1 & & \\
Quality (7) & $.428^{* *}$ & $.413^{* *}$ & $.348^{* *}$ & $.272^{*}$ & $.543^{* *}$ & $.491^{* *}$ & 1 & & \\
Speed(8) & $.324^{* *}$ & $.248^{*}$ & .121 & $.445^{* *}$ & $.713^{* *}$ & $.427^{* *}$ & $344^{* *}$ & 1 & \\
Flexibility (9) & $.411^{* *}$ & .113 & $.344^{* *}$ & $.290^{*}$ & $.631^{* *}$ & $.433^{* *}$ & $.432^{* *}$ & $.511^{* *}$ & 1
\end{tabular}

Note: *, **Significant at $\mathrm{P}<0.05$ and $\mathrm{P}<0.01$ (1-tailed), respectively $\mathrm{M.C}=$ Managerial Competencies, $\mathbf{S} . \mathbf{C}=$ Social Competencies, Prof. $\mathbf{C}=$ Professional Competencies, $\mathbf{P} . \mathbf{C}=$ Personal competencies. Source: Primary data.

As seen in Table III, $\mathrm{r}=.532, \mathrm{P} \leq .01$; there is a significant relationship between managerial competencies and supply chain performance of relief aid organizations in western Uganda. This finding is in support of $\mathrm{H} 1$. The positive association is an indicator that increase in managerial competencies results into an increase in supply chain performance of relief aid organizations in western Uganda.

\subsubsection{Regression analysis}

Hierarchical regression analysis was performed to determine the influence of the confounding variables (Years of service and cluster) and managerial competences in explaining the variations in supply chain performance of relief aid organizations in western Uganda.

Table IV Hierarchical Regression results

\begin{tabular}{lll} 
& $\begin{array}{l}\text { Model 1 } \\
\boldsymbol{\beta}\end{array}$ & $\begin{array}{l}\text { Model 2 } \\
\boldsymbol{\beta}\end{array}$ \\
\hline Years of service & .113 & .079 \\
Cluster & $.218^{*}$ & .098 \\
Managerial Competencies & & $.532^{* *}$ \\
$\mathbf{R}$ & .188 & .576 \\
$\mathbf{R}^{2}$ & .056 & .386 \\
Adjusted $\mathbf{R}^{2}$ & .069 & .347 \\
$\mathbf{R}^{2}$ Change & .056 & .330 \\
Sig. F-change & .301 & .000 \\
\hline
\end{tabular}

Note: *, **Significant at $\mathrm{P}<0.05$ and $\mathrm{P}<0.01$, respectively Source: Primary Data. 
The results are indicated in Table IV. From Table IV, the results in Model 1 show that confounding variables (Years of service and cluster) explain 5.6\% of the variance in supply chain performance and their contribution to performance is insignificant. The results in Model 2 show that on introduction of managerial competencies, the model explains $38.6 \%$ of the variance in supply chain performance. It further shows a statistically significant association between managerial competencies and supply chain performance and this is in support of $\mathrm{H} 1$.

\section{Discussion}

The study sought to establish the influence managerial competencies on supply chain performance of relief aid organizations in western Uganda. The study findings showed that, there is a significant and positive relationship between managerial competencies and supply chain performance. This implies that an increase in managerial competencies leads to an improvement supply chain performance in the humanitarian context. Study findings also showed that most of the respondents were graduates an indication that they acquired professional competencies from school and this is vital for performance. Additionally, it was found that managers who undertake relief supplies are experienced since they have served in their respective organizations for more than five years.

The study findings are in agreement with Kamukama et al., (2017) who posits that when an organization that has staff who have the right skills, knowledge and experience will make wise decisions which in turn make their organizations prosper. While the study was done in the banking sector in Uganda, the same is true for the humanitarian sector. Once relief aid organizations recruit and retain staff with social, professional and personal competencies, their supply chains will deliver relief supplies to the right beneficiaries, cost effectively and in a timely manner.

In the same voice, Kovacs et al., (2010) affirms that relief aid organizations who have staff with specific humanitarian skills register good performance. Likewise, Long et al., (2018); Seate et al (2016) also found a positive association between managerial competencies and performance. While their findings were in varied contexts and industries, the current study confirms that indeed managerial competencies are very crucial for supply chain performance in the humanitarian context. Similarly, studies by Ashley et al, (2016) indicate that an individual's performance is a precondition for supply chain performance. In agreement, Shanaka et al, (2017) found that special humanitarian skills that are crucial for supply chain performance.

Consistent with the Upper echelons theory (March \& Simon, 1958), competencies of managers are key for the performance of any organization. That any organization's good performance is attributed to the competencies of its top leadership and its network. The upper echelons theory looks at mangers as the vision bears considering their vintage point in terms of giving an organization strategic direction. This is important in humanitarian supply chains as these mangers will make decisions that influence short and long term decisions. In view of all the above it is clear that professional, social and personal competencies of staff of relief aid organizations are vital for relief aid organizations to deliver timely, quality, and cost effective supplies to the beneficiaries. 


\subsection{Conclusion}

From the study findings and discussion, the study concludes that managerial competencies is a strong predictor of supply chain performance among relief aid organizations in western Uganda. That with staff with social, professional and personal competencies, relief aid organizations in western Uganda will register improved supply chain performance.

\subsection{Implications}

From a theoretical perspective, considering the limited literature on relief operations in the developing country, the study makes a contribution to the body of knowledge.

From a managerial perspective, for supply chain to be realized, relief aid organizations in western Uganda need to recruit staff with professional, social and personal competencies so as to ensure that relief supplies each the intended beneficiaries.

\subsection{Limitations}

The study did not examine the influence of other factors such as the other supply chain enablers which include infrastructure on humanitarian supply chain performance. The focus was on the influence of managerial competencies on supply chain performance. Also, since this was a cross sectional study, the managerial competencies of staff could change over time probably through stakeholder engagement or training. Notwithstanding the above limitations, the study furthers the debate on the contribution of managerial competencies on supply chain performance of relief aid organizations in western Uganda.

\subsection{Recommendations}

From the study findings, it is recommended that relief aid organizations should recruit staff with professional, social and personal competencies to execute supply chain activities in humanitarian operations in western Uganda. . Additionally, relief aid organizations in western Uganda should widen their recruitment base to outside the humanitarian industry so as to attract staff with different levels of experience, attitude and qualifications so as to facilitate innovation in supply chain activities. It is also recommended that training programs aimed at performance improvement are instituted so as to improve supply chain performance.

\subsection{Areas for further study.}

Considering that this was across-sectional study and with more training and the changing operational environment in the humanitarian supply chains, more studies could follow a longitudinal approach so as to evaluate performance over time. Additionally, since the current study only focused on managerial competencies as a predictor of supply chain performance among relief aid organizations in western Uganda, more studies could examine the influence of other factors like operational environment, technology, infrastructure and financing. 


\section{References}

Abdifatah, H. M. (2012). Supply chain management practices and their impact on performance among humanitarian organizations in Kenya (Doctoral dissertation, University of Nairobi, Kenya).

Beamon, B. M., \& Balcik, B. (2008). Performance measurement in humanitarian relief chains. International Journal of Public Sector Management, Vol. 21 No. 1, pp. 4-25.

Ben Parker. (2018). Audit finds UN refugee agency critically mismanaged donor funds in Uganda. The New Humanitarian. $28^{\text {th }}$ November, 2018. Retrieved $20^{\text {th }}$ November 2018.

Biryabarema Elias. (2018). Uganda to widen relief fraud probe to UN staff, vows reforms. Reuters. $15^{\text {th }}$ February, 2018. Retrieved $20^{\text {th }}$ February 2018.

Blecken, A. (2010), "Supply chain process modelling for humanitarian organizations", International Journal of Physical Distribution and Logistics Management, Vol. 40 Nos 8/9, pp. 675-692.

Blecken, A., Hellingrath, B., Dangelmaier, W., \& Schulz, S. F. (2009). A humanitarian supply chain process reference model. International Journal of Services Technology and Management, 12(4), 391-413.

Cetin., A.T. (2010), Effects of human resource, marketing and manufacturing, performance on financial performance, Journal of Global Strategic Management

Christopher, M., \& Tatham, P. (2011). Humanitarian Logistics: Meeting the Challenge of Preparing For and Responding To Disasters. (M. C. P. Tathem, Ed.) Humanitarian Logistics: Meeting the Challenge of Preparing For and Responding To Disasters. London

Council of Supply Chain Management Professionals, CSCMP (2010). CSCMP supply chain management.

Creswell, J. W. (2013). Steps in conducting a scholarly mixed methods study.

Essex, A., Subramanian, N., \& Gunasekaran, A. (2016). The relationship between supply chain manager capabilities and performance: empirical evidence. Production Planning \& Control, 27(3), 198-211.

Field, A. (2009). Discovering statistics using SPSS. Sage Publications

Finkelstein, S., Hambrick, D.C. and Cannella, A. (2009), Strategic Leadership: Theory and Research on Executives, Top Management Teams, and Boards, Oxford University Press, Oxford

Fornell, C., \& Larcker, D. F. (1981). Evaluating structural equation models with unobservable variables and measurement error. Journal of Marketing Research, 18(1), 39-50. https://doi.org/10.2307/3151312

Francis Kasekende, John C. Munene Joseph Mpeera Ntayi Augustine Ahiauzu , (2015),"The interaction effect of social exchanges on the relationship between organizational climate and psychological contract", Leadership \& Organization Development Journal, Vol. 36 Iss 7 pp. 833 - 848: http://dx.doi.org/10.1108/LODJ-01-2014-0007

Grant, R.M. (2005), Contemporary Strategy Analysis, 5th ed., John Wiley \& Sons, New York, NY.

Haavisto, I., \& Kovács, G. (2014). Perspectives on sustainability in humanitarian supply chains. Disaster Prevention and Management. 
Haddad, H. (2017). Impact of Human Competencies on Caritas Jordan Employees Performance. Journal of Resources Development and Management, 1(28), 57-71.

Hambrick, D. C., \& Mason, P. A. (1984). Upper echelons: The organization as a reflection of its top managers. Academy of management review, 9(2), 193-206.

Idaszak, J. R., \& Drasgow, F. (1987). A revision of the Job Diagnostic Survey: Elimination of a measurement artifact. Journal of applied psychology, 72(1), 69.

Kabasongora, M. (2011). Food shortage hits Nakivale settlement camp. URN. 04 ${ }^{\text {th }}$ October 2011. Retrieved $10^{\text {th }}$ February 2018.

Kamukama, N., Kyomuhangi, D. S., Akisimire, R., \& Orobia, L. A. (2017). Competitive advantage. African Journal of Economic and Management Studies.

Kovács, G., \& Tatham, P. (2010, January). What is special about a humanitarian logistician? A survey of logistic skills and performance. In Supply Chain Forum: An International Journal (Vol. 11, No. 3, pp. 32-41). Taylor \& Francis.

Kovács, G., Tatham, P., \& Larson, P. D. (2012). What skills are needed to be a humanitarian logistician?. Journal of Business Logistics, 33(3), 245-258.

Kunz, N., \& Reiner, G. (2012). A meta-analysis of humanitarian logistics research. Journal of Humanitarian Logistics and Supply Chain Management.

Long, C. S., Fei, G. C., Amechi, U. C., \& Kowang, T. O. (2018). The Relationship between HR Competencies and Organizational Performance in the Banking Sector in Nigeria. International Journal of Human Resource Studies, 217-235.

Magadi.W. B. \& Noor, S., (2018) Role of Humanitarian Logistics on supply chain performance in Non government organizations in Keyna. A case of ACTED Kenya. International Journal of Management and Commerce, 5(2), (67-71).

Maghsoudi, A., Zailani, S., Ramayah, T., \& Pazirandeh, A. (2018). Coordination of efforts in disaster relief supply chains: the moderating role of resource scarcity and redundancy. International Journal of Logistics Research and Applications, 21(4), 407-430.

Majewski, B., Navangul, K. A., Heigh, I. (2010), "A Peek into the Future of Humanitarian Logistics: Forewarned is Forearmed”, Supply Chain Forum, Vol. 11, No. 3, pp. 4-19.

March, J.G. and Simon, H.A. (1958), Organizations, John Wiley, New York, NY.

Nyamu, T. K. (2012). Impact of supply chain management challenges on humanitarian organizations in Kenya (Doctoral dissertation).

Onyango, D. A. (2016). Knowledge management capabilities and performance of international humanitarian organizations in Kenya (Doctoral dissertation, University of Nairobi).

Rajakaruna Shanaka., Wijeratne, A. W., Mann, T., \& Yan, C. (2017). Effect of Individual Skills and Performance on Humanitarian Organizations: A Structural Equation Model. Logistics, $1(1), 7$.

Schulz, S. F., \& Heigh, I. (2009). Logistics performance management in action within a humanitarian organization. Management Research News.

Seate, B. M., Pooe, R. I., \& Chinomona, R. (2016). The relative importance of managerial competencies for predicting the perceived job performance of Broad-Based Black Economic Empowerment verification practitioners. SA Journal of Human Resource Management, 14(1), 1-11. 
Sserunjogi, E.M. (2018, February $10^{\text {th }}$ ). Refugee scandal the inside story. Daily Monitor . Retrieved $13^{\text {th }}$ February, 2018.

Strakos, J. K. (2013). Disaster relief supply chain management: The effect of organizational factors on improvisation and performance (Doctoral dissertation).

Tchaikovsky, Z. (2017). The Relationship Between Sustainable Supply Chain Management, Stakeholder Pressure, and Financial Performance.

Turyamureeba, R. (2017). Building Peace through land access and food security in the Nakivale Refugee Settlement, Uganda (Doctoral dissertation).

Uganda Government, Office of the Prime Minister (OPM). 2017. Monthly Refugee Statistics Update [31 July 2017], Refugee Information Management System (RIMS)

Van Wassenhove, L. N. (2006). Humanitarian aid logistics: Supply chain management in high gear. Journal of the Operational research Society, 57(5), 475-489.

Veliu, L., \& Manxhari, M. (2017). The impact of managerial competencies on business performance: SME's in Kosovo. Journal of Management, 30(1), 59-65. 